\title{
On the Role of Systems of Small Intensive Irrigation in Solving the Problems of Mineral Farming in Azerbaijan
}

\author{
Zakir Husein Oglu Aliyev* \\ Institute of Erosion and Irrigation NAS of Azerbaijan, Azerbaijan \\ Received: December 20, 2017; Published: January 18, 2017 \\ *Corresponding author: Zakir Husein Oglu Aliyev, Institute of Erosion and Irrigation NAS of Azerbaijan, Azerbaijan
}

\begin{abstract}
The authors note that currently in the country from the total turnover of land large areas are excluded that are unsuitable for agricultural production because of the construction of individual buildings and structures, the rise of the groundwater level, the development of various types of erosion and for both reasons. At the same time, there is an acute shortage of water in the country. Consequently, through the introduction of scientifically significant advanced irrigation technologies and methods of agricultural techniques (minimum depth) of soil treatment, it will allow the development of additional areas of sloping terrain, which will enable it to cope with this problem and achieve its goals
\end{abstract}

Keywords: Water resources, Erosion; Arable land; Agricultural production; Global warming; Irrigated lands; Irrigation

\section{Introduction}



Figure 1.

The total area of the Republic of Azerbaijan is 8641500 hectares of land, of which 55 per cent (4 756500 ha) are suitable for agriculture, and that 16.6 per cent of the total area or 1432600 ha of irrigated land accounted for. 1808400 hectares out of the total balance of the land belongs to the arable, that is suitable for agricultural production (Figure 1). It should be noted that of the total area of 181600 hectares of arable land are a controversial issue in the conditioning of Armenia. Currently more than $42.8 \%$ of the whole territory of the Republic (70 ... 85\% in some regions) are exposed to a variety of erosional processes [1]. The issue of the availability of suitable water resources for agriculture. It should be recognized that one person in 1959 year accounted for 0.36 ha of arable land in 1970 year-0.23 HA, in 1979 year-0.21 HA in 2006, fell to $0.155 \mathrm{HA}$. The authors of this article estimates that water resources accounts for 32.5 billion $\mathrm{m} 3$, and in dry years this figure is reduced to 23.16 billion $\mathrm{m} 3$.

The results of the study revealed that up to $96 \%$ of irrigated land irrigated mainly traditional irrigation techniques (furrow and puffed, superficial way), and in other ways using progressive water saving low-intensity irrigation technology only to $5 \%$ of the total irrigated land [2]. Of the total 224700 hectares of arable land are occupied by permanent crops, 117600 hectares are hayfields, $256.0 \mathrm{k}$. hectares of pastures, 45.7 thousand. HA-fallow land, smallholdings-258 100 hectares (227 600 hectares of arable), 1038800 HA included in share of regional forest plantations [3]. With the increase in population (currently there are about 10 million people) of land allocated for construction of buildings and constructions, etc. resulting in rise in groundwater levels, develop various types of erosion. As a result of incorrect reference soil-conservation activities at production facilities in selected households and violations of rules on cultivation of environmentally sound technologies (including agricultural machinery) area arable land per capita has been declining annually. So, one person in 1959 year accounted for 0.36 ha of arable land in 1970 year- $0.23 \mathrm{HA}$, in 1979 year- $0.21 \mathrm{HA}$ in 2006 , fell to 0.155 ha [4]. $60 \%$ of the entire territory are located in the mountainous part of the Republic. Due to the impact of natural and anthropogenic factors here can meet all types of erosion [5]. Based on the results of numerous research articles by the authors in the study of the regularities of 
the development problems of land degradation and landscape in some regions, it was found that the erosion process has a very wide distribution (especially in mountainous terrain) in the Republic of Azerbaijan. As stated above, more than 42.8 per cent of the country is exposed to a variety of erosional processes [6]. One of the biggest factors is water and irrigation erosion.

\section{The Course of Study}

The predominant use of the method of irrigation by furrows and puffed, agrotechnical measures which (regardless of any protection lands, agriculture, horticulture and animal husbandry) cause soil erosion [2]. The author of the article estimated water resources accounts for 32.5 billion $\mathrm{m} 3$, and in dry years this figure is reduced to 23.16 billion m3. According to research by 2020, total annual values of water resources per capita in Azerbaijan will be 2 times less than in Armenia, and 7 times less than in Georgia. The volume of water resources in the country is only $30 \%$, and the remaining $70 \%$ of the total water sources are the main flow through neighbouring countries [7]. It should be noted that in the context of permanent water shortages despite sharply unequal distribution of water in the country, thanks to the traditional forms of irrigation, there is a noticeable environmental and economic effect of reclamation activities. It is proposed to bring efficiency in the production of agricultural crop production unit from using water resources to the year 2025 at the level of $1 \mathrm{~kg} / \mathrm{m} 3$ and at the level of $1.5 \mathrm{~kg} / \mathrm{m} 3$ to year 2050 .

\section{Discuss the Results of the Study}

The results of the study revealed that up to $96 \%$ of irrigated land irrigated mainly traditional irrigation techniques (furrow and puffed, superficial way), and in other ways using progressive water saving low-intensity irrigation technology only to $5 \%$ of the total irrigated land. Therefore, the groundwater level is increasing every day. But in some areas the ground water salinization and were at present there are about 100 thousand. HA suitable arable land. This and raises the risk of violation of the ecological balance in the country. Currently, more than 53 thousand hectares of sown areas Kura-Araks Lowland classified as strongly saline soils due to the increased level of ground saline water, so these lands came from crop rotation (household plots the population of these regions of Azerbaijan). Requires thorough washing of these soils from harmful salts of all kinds [2,7]. The results of monitoring studies revealed comparative indicators on vodoobespechanosti 3-piece States: Georgia, Armenia and Azerbaijan, which respectively accounted for 70, 25 and 10 billion KM3. Summary annual (per capita) water resources in these countries accordingly made 11000, 3000 and
$1500 \mathrm{~m} 3 /$ person. According to research by 2020, total annual values of per capita water resources of Azerbaijan in 2 times less than in Armenia, and 7 times less than in Georgia.

The authors of the article pay attention that water resources are very important for the development of the economies of the region, especially for industrial production and agriculture, which are the key types of employment [7]. Finally, in recent decades the world population annually increases dramatically compared to the population of the Earth in 2.5 billion people in the year 1950 . Demand for food is growing faster than population growth. Growing population and limited land and water resources require serious measures to ensure food without-dangers of all States. Agricultural production must produce a large amount of crop production, which requires large amounts of irrigation water. The aim of realization of the State program of the Republic of Azerbaijan in the year 2015 was 11.2 tons production per capita agricultural production. While the concept of a global climate change shows and proves that it is not currently possible to quickly ramp up the required water for agricultural purposes. Nevertheless, the value of agricultural production and water consumption are increasing. The scientific and practical methods and advanced irrigation technology and science-based farming methods and rules should help to cope with this problem and achieve your goals. Worldwide, countries are struggling with a shortage of irrigation water. Azerbaijan also seeks to balance the needs of water demand for agriculture. It is planned to bring efficiency in the production of agricultural crop production unit from using water resources to the year 2025 at the level of 1 $\mathrm{kg} / \mathrm{m} 3$ and at the level of $1.5 \mathrm{~kg} / \mathrm{m} 3$ to 2050 Goh doo

\section{References}

1. ZH Aliev (2016) Scientific substantiation of rational irrigation technologies for mountain agriculture regions in the Republic of Azerbaijan. ecology and construction 1: 20-25.

2. Aliev GA (1978) Soils of the Greater Caucasus within the Azerbaijan SSR. Baku Elm pp.157.

3. Aliev BH, Aliev ZH, Aliyev IN (2000) Problems of erosion in Azerbaijan and ways of its solution. Publishing house Ziya CPI Nurlan p.12.

4. Losev KS, Gorshkov VGK (1993) Kondratiev I etc. Ecological problems in Russia. In N Nekrasov (1972) Regional eco logistics. pp.160.

5. Dolgopolov K, Fedorova EF (1973) National Water heritage. M knowledge p.53.

6. Losev KS, VG Gorshkov (1974) condensed to ratev I, etc. Biological productivity of the Caspian Sea. pp. 245.

7. Gul KK, Lappalainen TN, Poluzhkin VA (1970) Caspian Sea abstract collection information. pp.236. 
(C) C) $\begin{aligned} & \text { This work is licensed under Creative } \\ & \text { Commons Attribution } 4.0 \text { License }\end{aligned}$

DOI: 10.32474/CIACR.2018.01.000102

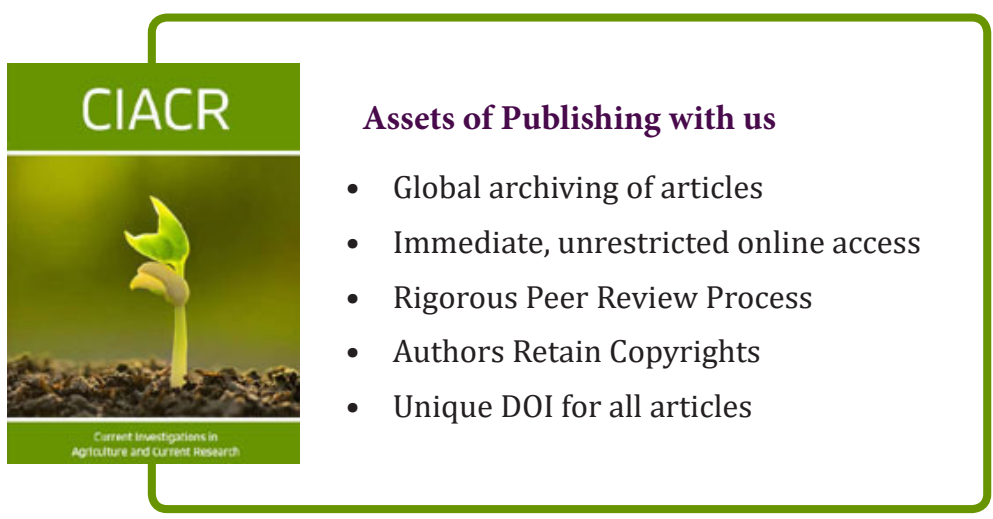

